\title{
Altitudinal Change in the Photosynthetic Capacity of Tropical Trees: A Case Study from Ecuador and a Pantropical Literature Analysis
}

\author{
Bärbel Wittich, Viviana Horna, Jürgen Homeier, and Christoph Leuschner*
}

Plant Ecology, Albrecht von Haller Institute for Plant Sciences, University of Göttingen, Untere Karspüle 2, 37073 Göttingen, Germany

\begin{abstract}
In tropical mountains, trees are the dominant life form from sea level to above 4,000-m altitude under highly variable thermal conditions (range of mean annual temperatures: $<8$ to $>28^{\circ} \mathrm{C}$ ). How light-saturated net photosynthesis of tropical trees adapts to variation in temperature, atmospheric $\mathrm{CO}_{2}$ concentration, and further environmental factors, that change along elevation gradients, is not precisely known. With gas exchange measurements in mature trees, we determined light-saturated net photosynthesis at ambient temperature $(\mathrm{T})$ and $\left[\mathrm{CO}_{2}\right]\left(A_{\text {sat }}\right)$ of 40 tree species from 21 families in tropical mountain forests at 1000-, 2000-, and 3000-m elevation in southern Ecuador. We tested the hypothesis that stand-level averages of $A_{\text {sat }}$ and leaf dark respiration $\left(R_{\mathrm{D}}\right)$ per
\end{abstract}

Received 22 September 2011; accepted 15 April 2012; published online 29 June 2012

Electronic supplementary material: The online version of this article (doi:10.1007/s10021-012-9556-9) contains supplementary material, which is available to authorized users.

Author Contribution: Christoph Leuschner and Vivana Horna designed the study, Jürgen Homeier conducted the species identification and helped with the selection of species, Bärbel Wittich performed the field research with support of B. Wittich, V. Horna, and J. Homeier analyzed the data, and C. Leuschner, V. Horna, and B. Wittich wrote the article. *Corresponding author; e-mail: cleusch@gwdg.de leaf area remain constant with elevation. Standlevel means of $A_{\text {sat }}$ were $8.8,11.3$, and $7.2 \mu \mathrm{mol}$ $\mathrm{CO}_{2} \mathrm{~m}^{-2} \mathrm{~s}^{-1}$; those of $R_{\mathrm{D}} 0.8,0.6$, and $0.7 \mu \mathrm{mol}$ $\mathrm{CO}_{2} \mathrm{~m}^{-2} \mathrm{~s}^{-1}$ at 1000-, 2000-, and 3000-m elevation, respectively, with no significant altitudinal trend. We obtained coefficients of among-species variation in $A_{\text {sat }}$ and $R_{\mathrm{D}}$ of $20-53 \%(n=10-16$ tree species per stand). Examining our data in the context of a pan-tropical $A_{\text {sat }}$ data base for mature tropical trees (c. 170 species from 18 sites at variable elevation) revealed that area-based $A_{\text {sat }}$ decreases in tropical mountains by, on average, $1.3 \mu \mathrm{mol} \mathrm{CO}_{2} \mathrm{~m}^{-2} \mathrm{~s}^{-1}$ per $\mathrm{km}$ altitude increase (or by $0.2 \mu \mathrm{mol} \mathrm{CO} \mathrm{Cm}^{-2} \mathrm{~s}^{-1}$ per $\mathrm{K}$ temperature decrease). The $A_{\text {sat }}$ decrease occurred despite an increase in leaf mass per area with altitude. Local geological and soil fertility conditions and related foliar $\mathrm{N}$ and $\mathrm{P}$ concentrations considerably influenced the altitudinal $A_{\text {sat }}$ patterns. We conclude that elevation is an important influencing factor of the photosynthetic activity of tropical trees. Lowered $A_{\text {sat }}$ together with a reduced stand leaf area decrease canopy $\mathrm{C}$ gain with elevation in tropical mountains.

Key words: altitudinal gradient; foliar N; foliar P; leaf dark respiration; light-saturated net photosynthesis; tropical lowland forests; mature trees; C source limitation; tropical montane forests. 


\section{INTRODUCTION}

With an estimated total of 37,000 woody plants (Odegaard 2000), tropical forests possess not only by far more tree species, but also exist under a broader spectrum of environmental conditions, than any other biome on earth. Moist forests once stretched from sea level to the alpine tree line at 3,500$4,800 \mathrm{~m}$ a.s.l., forming closed stands under a very broad range of mean annual temperatures (MAT; $>28$ to $<8^{\circ} \mathrm{C}$ ), rainfall totals (from c. 2,000 to $>8,000 \mathrm{~mm} \mathrm{y}^{-1}$ ) and soil fertility conditions (very low to high fertility; Whitmore 1998; Ghazoul and Sheil 2010). As a consequence, tropical forests exhibit large changes in structure, physiognomy, and species composition as one ascends from the lowlands to high elevation. Tropical mountain forests (TMFs) replace lowland forests at approximately 1,000-m elevation, where the climate becomes cooler and often moister, and radiation is frequently reduced due to cloudiness (Hamilton and others 1995; Bruijnzeel and others 2010). Other influential environmental factors that change with altitude are air pressure and the atmospheric concentrations of $\mathrm{CO}_{2}$ and $\mathrm{O}_{2}$, and UV-B radiation. In many altitudinal transects in tropical mountains, soil moisture tends to increase and the plant availability of nutrients, in particular of nitrogen and phosphorus, to decrease with altitude (Soethe and others 2008; Benner and others 2010; Bruijnzeel and others 2010; Moser and others 2008).

Tropical trees seem to respond to altitudinal gradients by modifications in plant form and function, notably adaptation in leaf morphology and physiology, tree stature, carbon allocation patterns, and productivity (for example, Cordell and others 1999; Moser and others 2007, 2008, $2011)$ but the within-species variation in morphological and functional traits in response to increasing elevation is not well studied. More information exists about community level changes in tree stature, leaf form and function, and forest productivity along elevation transects in tropical mountains which result from species turnover along the slope. One of the most obvious changes is the reduction in tree size (Lieberman and others 1996; Raich and others 1997; Aiba and Kitayama 1999; Pollmann and Hildebrand 2005; Shi and others 2008), which is accompanied by a reduction in aboveground net primary production (NPP) from tropical lowland to upper montane forests (Hawaii: Raich and others 1997; Sabah, Malaysia: Kitayama and Aiba 2002; Puerto Rico: Weaver and Murphy 1990, Wang and others 2003; Peru: Girardin and others 2010; Ecuador: Moser and others 2011;
Leuschner and others, in press). One of the possible underlying causes is the temperature decrease, but $\mathrm{N}$ limitation of tree growth may also be involved in certain mountains where a decrease of foliar $\mathrm{N}$ concentration and an increase in leaf longevity with elevation was found (for example, Tanner and others 1998; Letts and Mulligan 2005; Moser and others 2010). Grubb and Tanner (1976) and Grubb (1977) identified smaller and thicker leaves with lower $\mathrm{N}$ concentrations as being characteristic for the trees at high elevations in tropical mountains.

Leaf level photosynthesis, the process that defines canopy carbon gain, has only rarely been investigated in TMFs (for example, Hikosaka and others 2002; Rada and others 2009; van de Weg and others 2012). In general, we know more about the photosynthetic activity of trees at the alpine tree line and their carbon relations than about altitudinal change in tree photosynthetic capacity in mountain forests, both in the tropical and the temperate regions (for example, Rada and others 1996; Hoch and others 2002; Körner 2003; Smith and Johnson 2009). However, examining how light-saturated net photosynthesis $\left(A_{\text {sat }}\right)$ and canopy $\mathrm{C}$ gain change along mountain slopes from lowland to upper montane elevation is crucial for a better understanding of the long-term adaptation of trees to changes in temperature, atmospheric $\mathrm{CO}_{2}$ concentration, and other abiotic factors, and it may also help to answer the question about the causes of tropical alpine tree lines.

Altitudinal change in $A_{\text {sat }}$ has been investigated in a few temperate and subtropical mountains (for example, Benecke and others 1981; Zhang and others 2005; Premoli and Brewer 2007; Wieser and Tausz 2007; Bresson and others 2009) showing either no change (Benecke and others 1981; Wieser and Tausz 2007; Bresson and others 2009; Wieser and others 2010), an increase (Premoli and Brewer 2007) or a decrease with increasing altitude (Slayter and Morrow 1977; Zhang and others 2005). Thus, no consistent pattern has yet been detected. Even less is known about altitudinal change in the $A_{\text {sat }}$ of tropical trees. A notable exception is the altitudinal transect study in Metrosideros polymorpha in the tropical island forests of Hawaii between 100 and 2,500 m a.s.l. (Cordell and others 1998, 1999).

In this transect study in southern Ecuadorian TMFs, we examined patterns of altitudinal variation in light-saturated net photosynthesis of mature (or pre-mature) trees along a transect from 1,000 to 3,000 $\mathrm{m}$ a.s.l. covering a large number of tree species (40). We further explored the possible dependence of $A_{\text {sat }}$ on foliar nutrient concentration and leaf 
morphology along the elevation gradient. Complementary to this field study, we conducted a pantropical literature survey of published photosynthesis data from mature tropical trees at contrasting elevation (lowland to upper montane; 12 studies from 22 sites covering more than 150 tree species, excluding seedling and sapling studies). The main objectives of the study were (i) to clarify the position of tropical montane forest trees relative to tropical lowland, subtropical, and temperate trees in terms of leaf form and function and (ii) to search for a significant temperature and altitude dependence of $A_{\text {sat }}$ and leaf dark respiration $R_{\mathrm{D}}$ in tropical trees. We tested the hypotheses that (1) stand-level averages of mass-based $A_{\text {sat }}$ are decreasing with elevation due to decreases in foliar N and $\mathrm{P}$, whereas (2) area-based $A_{\text {sat }}$ remains unchanged because of the LMA increase with altitude. We also hypothesized that (3) area-based $R_{\mathrm{D}}$ does not change with elevation.

\section{METHODS}

\section{Study Sites and Selection of Trees}

The measurements were conducted along a 2,000$m$ elevation transect in TMFs on the eastern slope of the southern Ecuadorian Andes between February and May 2009. The study sites were located at about 1000, 2000, and $3000 \mathrm{~m}$ a.s.l. in the Podocarpus National Park and the Reserva Biológica San Francisco in the Provinces of Loja and Zamora-Chinchipe. The maximum distance between the sites was $30 \mathrm{~km}$ (Figure 1).

The research area has a tropical humid climate with an extremely wet season from April to July and a less humid period from September to December (Bendix and others 2006). Regularly occurring longer dry periods do not exist. Further details on the climatic conditions at the study sites are given in Table 1 .

All three stands are located in protected forest sections. Natural disturbances in the past may have included landslides in the steeply sloped terrain. The three elevations along the gradient correspond to three different forest types (Homeier and others 2008): (1) at $1,000 \mathrm{~m}\left(4^{\circ} 7^{\prime} \mathrm{S} 78^{\circ} 58^{\prime} \mathrm{W}\right)$, in the transition zone between tropical lowland and lower montane forest, we find evergreen premontane forest whose trees attain heights of up to $40 \mathrm{~m}$. Common tree families of this forest type are Fabaceae, Melastomataceae, Moraceae, Myristicaceae, Rubiaceae, and Sapotaceae. In this forest, we selected one tree individual per species, totaling to 15 species, at elevations between 950 and $1,050 \mathrm{~m}$ a.s.l. Ten species were identified to the species level (see Table 3), the remaining to the genus level. (2) The evergreen lower montane forest at $2,000 \mathrm{~m}$ $\left(3^{\circ} 58^{\prime} \mathrm{S} 79^{\circ} 04^{\prime} \mathrm{W}\right)$ achieves a canopy height of 18-22 m. Characteristic tree families are Euphorbiaceae, Lauraceae, Melastomataceae, and Rubiaceae. Sixteen tree species were investigated at elevations between 1,800 and 1,900 $\mathrm{m}$ a.s.l. Fourteen of the sixteen species could be identified to the species level. (3) The evergreen elfin-forest at 3,000 $\mathrm{m}\left(4^{\circ} 7^{\prime} \mathrm{S}\right.$ $79^{\circ} 11^{\prime} \mathrm{W}$ ) extends up to the tree line, and the canopy height is rarely higher than $8-10 \mathrm{~m}$. Dominant tree families are Aquifoliaceae, Clusiaceae, Cunionaceae, Lauraceae, and Melastomataceae. Ten tree species were investigated at elevations between 2,850 and 3,000 $\mathrm{m}$ a.s.l. situated about $100-200 \mathrm{~m}$ below the tree line; nine were identified to the species level. Stand structural characteristics of the three stands are summarized in Table 2.

In the three stands, photosynthesis measurements were conducted on a total of 41 trees representing 40 different species (in one species, Clethra revoluta, we selected one individual at 2,000 and at 3,000 m). Only medium to tall trees with a minimum breast height diameter (dbh) of $10 \mathrm{~cm}$ were investigated (the mean dbh of the sampled trees was $16 \pm 2 \mathrm{~cm}$ at $1,000 \mathrm{~m}, 19 \pm 2 \mathrm{~cm}$ at $2,000 \mathrm{~m}$, and $12 \pm 1 \mathrm{~cm}$ at $3,000 \mathrm{~m}$ ). The size of the measured trees was $10-20 \mathrm{~m}$ at $1,000 \mathrm{~m}$, $8-15 \mathrm{~m}$ at $2,000 \mathrm{~m}$, and $4-12 \mathrm{~m}$ at $3,000 \mathrm{~m}$. To gain access to the sun-lit parts of the tree canopies, we selected tree individuals in the forest that grew on the steep slope beneath walking paths or below ribs on the slope, so that part of the canopy exposed to the sun could be approached from the ground.

We compiled data on the geographical distribution of the sampled families and the known altitudinal distribution of the investigated species using the online databases established by Stevens (2010) and the Missouri Botanical Garden (2010). We used APG III (2009) for family classification.

\section{Photosynthesis Measurements}

Light-saturated net photosynthesis $A_{\text {sat }}$ was measured on about 50 days between February and May 2009 with a portable IRGA system (LI-6400, LI-COR Biosciences, Lincoln, Nebraska, USA) with a standard leaf chamber equipped with a LED red/ blue light source (type 6400-02B). All measurements were performed between 10:00 a.m. and 4:00 p.m. Three fully expanded leaves of the most distal insertion on intact twigs exposed to full sunlight were investigated per tree. Thus, every species was represented by one tree individual and three leaves. Light-saturated net photosynthesis 
Table 1. Climatic and Edaphic Characteristics of the Sampled Stands

\begin{tabular}{|c|c|c|c|}
\hline Elevation (m a.s.l.) & 1,000 & 2,000 & 3,000 \\
\hline Rainfall $\left(\mathrm{mm} \mathrm{y}^{-1}\right)$ & c. 2,230 & c. 1,950 & c. 4,500 \\
\hline \multicolumn{4}{|l|}{ Air temperature $\left({ }^{\circ} \mathrm{C}\right)$} \\
\hline Mean & 19 & 16 & 9 \\
\hline Max & 30 & 29 & 19 \\
\hline Min & 12 & 8 & 3 \\
\hline \multicolumn{4}{|l|}{ Air humidity (\%) } \\
\hline Mean & 86 & 91 & 94 \\
\hline Max & 100 & 100 & 100 \\
\hline Min & 16 & 29 & 29 \\
\hline$\left[\mathrm{CO}_{2}\right](\mathrm{Pa})$ & 33 & 30 & 27 \\
\hline $\mathrm{pH}\left(\mathrm{H}_{2} \mathrm{O}\right)$ & $4.3 \pm 0.6^{\mathrm{a}}$ & $4.8 \pm 0.5^{\mathrm{a}}$ & $3.7 \pm 0.1^{\mathrm{a}}$ \\
\hline $\mathrm{C} / \mathrm{N}\left(\mathrm{g} \mathrm{g}^{-1}\right)$ & $19.0 \pm 2.5^{\mathrm{ab}}$ & $15.6 \pm 0.6^{\mathrm{a}}$ & $23.9 \pm 1.4^{\mathrm{b}}$ \\
\hline$P_{\mathrm{av}}\left(\mathrm{kg} \mathrm{ha}^{-1}\right)$ & $11.8 \pm 5.3^{\mathrm{a}}$ & $12.5 \pm 4.9^{\mathrm{a}}$ & $5.1 \pm 0.6^{\mathrm{a}}$ \\
\hline Net $\mathrm{N}$ mineralization $\left(\mathrm{kg} \mathrm{N} \mathrm{ha}^{-1} 10 \mathrm{~d}^{-1}\right)$ & $4.0 \pm 1.6^{\mathrm{a}}$ & $1.4 \pm 0.7^{\mathrm{ab}}$ & $0.6 \pm 0.4^{\mathrm{b}}$ \\
\hline \multicolumn{4}{|c|}{ 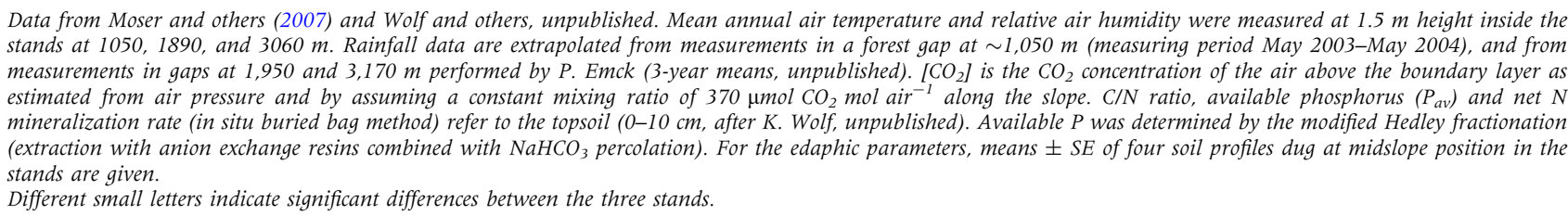 } \\
\hline
\end{tabular}

Table 2. Structural Characteristics of the Stands at 1000, 2000, and $3000 \mathrm{~m}$

\begin{tabular}{|c|c|c|c|c|c|c|c|c|}
\hline $\begin{array}{l}\text { Elevation } \\
\text { (m a.s.l.) }\end{array}$ & $\begin{array}{l}\text { Canopy } \\
\text { height (m) }\end{array}$ & $\begin{array}{l}\text { DBH }(\mathrm{cm}) \\
\text { Mean } \pm \mathrm{SE}\end{array}$ & $\begin{array}{l}\text { Stem density } \\
\left(\mathrm{n} \mathrm{ha}^{-1}\right) \\
\text { Mean } \pm \text { SE }\end{array}$ & $\begin{array}{l}\text { Basal area } \\
\left(\mathrm{m}^{2} \mathrm{ha}^{-1}\right) \\
\text { Mean } \pm \mathrm{SE}\end{array}$ & $\begin{array}{l}\text { LAI }\left(\mathrm{m}^{2} \mathrm{~m}^{-2}\right) \\
\text { Mean } \pm \mathrm{SE}\end{array}$ & $\begin{array}{l}\text { Leaf lifespan } \\
\text { (months) } \\
\text { Mean } \pm \text { SE }\end{array}$ & $\begin{array}{l}\text { AGB } \\
\left(\mathrm{Mg} \mathrm{ha}^{-1}\right) \\
\text { Mean } \pm \text { SE }\end{array}$ & $\begin{array}{l}\text { BGB } \\
\left(\mathrm{Mg} \mathrm{ha}^{-1}\right)\end{array}$ \\
\hline 1,000 & $25-30$ & $19 \pm 1^{a}$ & $822 \pm 50^{\mathrm{a}}$ & $29 \pm 4^{a}$ & $6.0 \pm 0.4^{\mathrm{a}}$ & $16 \pm 3^{a}$ & $177 \pm 28^{a}$ & 32.1 \\
\hline 2,000 & $16-20$ & $20 \pm 1^{a}$ & $900 \pm 62^{a}$ & $34 \pm 3^{a}$ & $5.7 \pm 0.5^{\mathrm{a}}$ & $24 \pm 2^{\mathrm{b}}$ & $158 \pm 22^{\mathrm{a}}$ & 26.1 \\
\hline 3,000 & $8-10$ & $18 \pm 1^{a}$ & $1,061 \pm 84^{a}$ & $30 \pm 3^{a}$ & $2.2 \pm 0.2^{\mathrm{b}}$ & $25 \pm 2^{b}$ & $89 \pm 10^{b}$ & 62.8 \\
\hline
\end{tabular}

After Homeier and others, unpublished; LAI, leaf lifespan, BGB, and leaf biomass: Moser and others 2007, 2011. Presented are mean \pm 1 SE for the three elevations (except for $B G B)$. Means of $D B H$, stem density, basal area, and $A G B$ were calculated for 9-18 permanent plots (400 $\mathrm{m}^{2}$ each) covering the whole range of topographic positions at the respective elevations (trees $>10 \mathrm{~cm} \mathrm{DBH}$ ).

$A G B$ aboveground biomass, BGB belowground biomass (coarse and fine roots), DBH diameter at breast height, LAI leaf area index.

Different small letters indicate significant differences between the three stands.

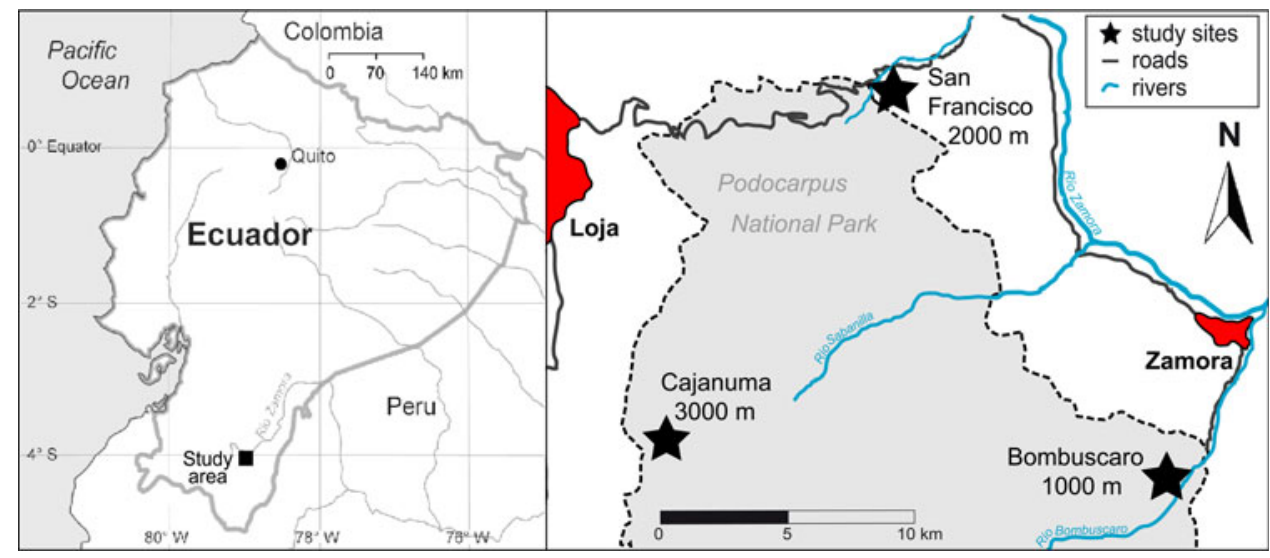

Figure 1. Location of the study area in southern Ecuador with the three stands at 1000, 2000, and $3000 \mathrm{~m}$ a.s.l.

was determined at a photon flux density of $1,500 \mu \mathrm{mol} \mathrm{m} \mathrm{m}^{-2} \mathrm{~s}^{-1}$ under ambient $\mathrm{CO}_{2}$ concentration and temperature. Before starting the measurement cycle of a light response curve, the leaves were exposed to high irradiance $\left(1,500 \mu \mathrm{mol} \mathrm{m} \mathrm{m}^{-2} \mathrm{~s}^{-1}\right)$ until apparent photosynthesis was stable $(\mathrm{CV} \leq 10 \%)$; this was achieved after 5-20 min. In the subsequently measured light 
levels, the gas exchange system was programmed to $5 \mathrm{~min}$ for stable values before taking a reading. The measurements were conducted at mixing ratios of $370 \mathrm{ppm} \mathrm{CO}_{2}$ at all sites and at cuvette temperatures of $22-24^{\circ} \mathrm{C}$ at $1,000 \mathrm{~m}, 19-21^{\circ} \mathrm{C}$ at $2,000 \mathrm{~m}$, and $15-17^{\circ} \mathrm{C}$ at $3,000 \mathrm{~m}$ to simulate the typical local sun-canopy temperatures on a sunny day at noon (based on temperature measurements by Rollenbeck and Peters, unpublished data). The vapor pressure deficit was held constant at ambient conditions at the three sites. The $\mathrm{CO}_{2}$ release in the dark was used as an estimate of leaf dark respiration $\left(R_{\mathrm{D}}\right)$. Prior to $R_{\mathrm{D}}$ measurement, the intact leaves on the branches were allowed to acclimate to the dark in the chamber for 2-5 min. At the beginning of the measuring campaign, the $\mathrm{CO}_{2}$ analyzer was calibrated against a gas standard of $400 \mathrm{ppm} \mathrm{CO}_{2}$ in $\mathrm{N}_{2}$. The IRGA channels were matched before each measurement. We did not check the respiration data for the possible occurrence of post-illumination burst effects; however, our $R_{\mathrm{D}}$ data compare well with leaf dark respiration rates reported from other neo- and paleotropical tree species (for example, Eschenbach and others 1998; Carswell and others 2000; Kenzo and others 2004; Meir and others 2007).

\section{Morphological and Chemical Leaf Traits}

All investigated leaves were harvested for analysis of foliar $\mathrm{N}$ and $\mathrm{P}$ concentrations. Total concentrations of foliar $\mathrm{N}$ were determined with a $\mathrm{C} / \mathrm{N}$ elemental analyzer (Vario EL III, Elementar, Hanau, Germany). Total P concentrations were analyzed using an Inductively Coupled Plasma Analyzer (Optima 5300DV ICP-OES, Perkin Elmer, Waltham, Massachusetts, USA) after digesting the samples with concentrated $\mathrm{HNO}_{3}$.

\section{Data Analysis}

The relationship between net photosynthesis rate and PPFD was described with a non-rectangular hyperbolic function; $90 \%$ of the $\mathrm{CO}_{2}$ assimilation rate at $1,500 \mu \mathrm{mol}$ photons $\mathrm{m}^{-2} \mathrm{~s}^{-1}$ was taken as $A_{\text {sat }}$. The initial slope of the light response curve was used to calculate the apparent quantum yield of $\mathrm{CO}_{2}$ assimilation $(\alpha)$. The data were analyzed at the stand level by pooling 10-16 species of a study site. Analysis of variance and Scheffé's test were used to conduct multiple comparisons among the means of the three stands. If the data were not normally distributed according to a Shapiro-Wilk test, the Mann-Whitney two-sample test (Wilcoxon $U$ test) was used instead of Scheffé's test. All calculations were conducted with SAS software (version 9.1; SAS Institute, Cary, North Carolina, USA). A significance level of $5 \%$ was used throughout the analyses.

\section{Pan-tropical Literature Survey}

A literature survey was conducted to compile a data base of $A_{\text {sat}}$, LMA and leaf nutrient values of trees from all over the tropics covering sites at variable altitudes from lowland to upper montane elevation (see Table 1 in Online supplementary material). This data base covers 13 studies (including the present one) with 169 more than 185 tree species in 25 stands located at elevations between 100 and $3,700 \mathrm{~m}$. Only measurements referring to mature or pre-mature tree individuals of non-pioneer stands were considered. Studies referring to seedlings or saplings were excluded. All study sites are located in moist tropical forests with more than $1,500 \mathrm{~mm}$ rainfall $\mathrm{y}^{-1}$. $A_{\text {sat }}$ values obtained at irradiances below $1,200 \mu \mathrm{mol}$ photons $\mathrm{m}^{-2} \mathrm{~s}^{-1}$ were only included if that flux density was identified as being saturating. If information was available, only data referring to sun-lit, fully expanded leaves of the upper canopy were included. Wet season data were given preference over dry season data if both were available.

\section{RESUltS}

Among the 40 tree species from 21 families investigated, light-saturated net photosynthesis at ambient temperature and $\left[\mathrm{CO}_{2}\right]$ conditions $\left(A_{\text {sat }}\right)$ varied in a broad range from 2.1 to $12.9 \mu \mathrm{mol}$ $\mathrm{CO}_{2} \mathrm{~m}^{-2} \mathrm{~s}^{-1}$ (Table 3, lowest value in Ilex teratopis $(3,000 \mathrm{~m})$, highest value in Tibouchina ochipetala, $1,000 \mathrm{~m}) . A_{\text {sat }}$ varied from 3.4 to $16.0 \mu \mathrm{mol} \mathrm{m}^{-2} \mathrm{~s}^{-1}$ in the stand at $1,000 \mathrm{~m}$ ( 15 species), from 7.7 to $15.4 \mu \mathrm{mol} \mathrm{m}{ }^{-2} \mathrm{~s}^{-1}$ at $2,000 \mathrm{~m}$ (16 species), and from 2.6 to $10.3 \mu \mathrm{mol} \mathrm{m}{ }^{-2} \mathrm{~s}^{-1}$ in the uppermost stand at 3,000 m (10 species). We obtained coefficients of variation (standard deviation expressed as percent of mean) for the species collectives investigated of $36 \%(1,000 \mathrm{~m}), 20 \%(2,000 \mathrm{~m})$, and $38 \%(3,000 \mathrm{~m})$ for the three stands.

We found no evidence in support of the assumption that trees from families restricted to the tropics generally had higher $A_{\text {sat }}$ values than members from families with tropical and extratropical distribution range. The 21 families investigated (each represented with 1-6 species in the study) are arranged in Figure 2 according to their mean photosynthetic capacity. Relatively, high $A_{\text {sat }}$ values were determined in members from the Clethraceae, Rubiaceae, Siparunaceae, and 


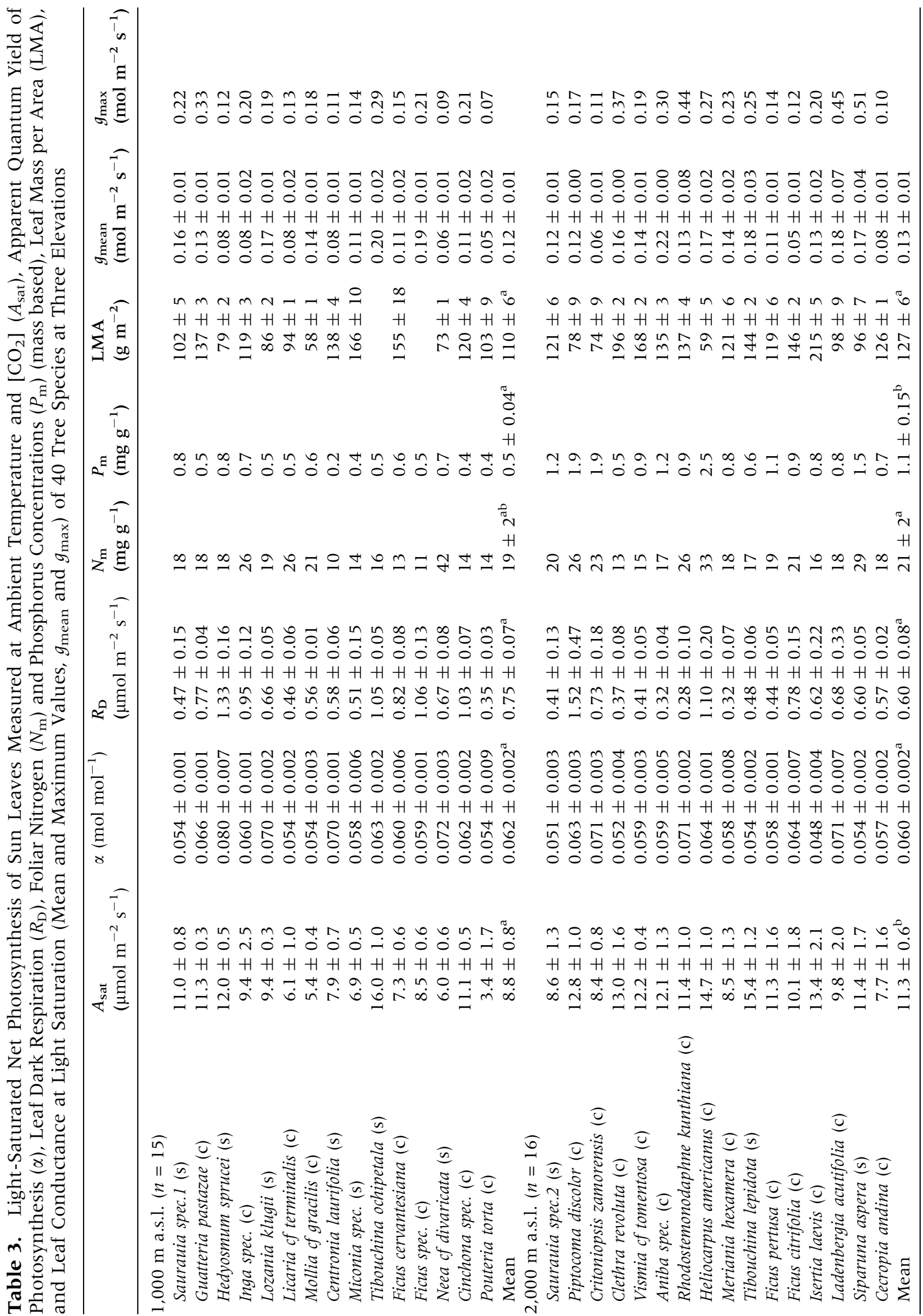




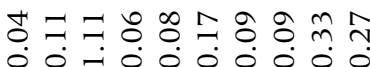

ஃ

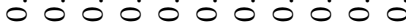

$H+H+H+H H+H H$

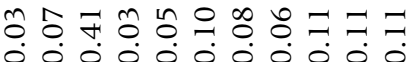

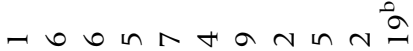

$\mathrm{H} H+\mathrm{H} H+\mathrm{H}+\mathrm{H} H+$

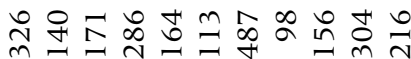

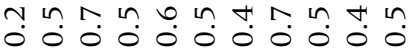

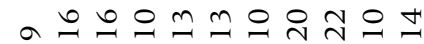

근

능

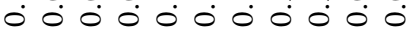
$H+H+H+H H H+H H$

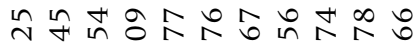
$000 \dot{0} 0000000$

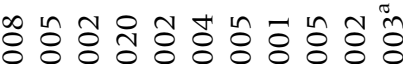

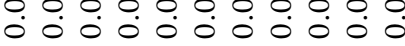
$H+H+H+H+H+H+H$

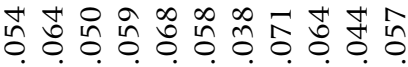

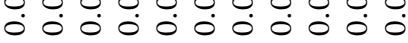
ֻัด $H+H+H+H+H+H+H$

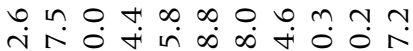

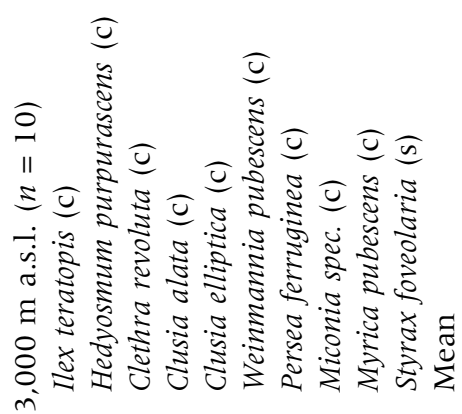

Anonaceae; low rates, in trees from the Clusiaceae, Nyctaginaceae, Sapotaceae, and Aquifoliceae.

In our species sample from southern Ecuador, we found no clear elevational trend in $A_{\text {sat }}$ with stand means of $8.8(1,000 \mathrm{~m}), 11.3(2,000 \mathrm{~m})$, and $7.2 \mu \mathrm{mol} \mathrm{CO} \mathrm{Cm}^{-2} \mathrm{~s}^{-1}(3,000 \mathrm{~m})$. However, the 16 species of the montane stand at $2,000 \mathrm{~m}$ had on average significantly higher photosynthetic capacities than the trees at 1,000 or $3,000 \mathrm{~m}$ (Table 3). This is also visible in Figure 2 when comparing the species of a family at 2,000 $\mathrm{m}$ (triangles) with the members from 1,000 or 3,000 m (squares and circles).

We found apparent quantum yields $(\alpha$, the initial slope of the light response curve under ambient $\mathrm{T}$ and $\left.\left[\mathrm{CO}_{2}\right]\right)$ in the range of $0.037-0.080 \mathrm{~mol}$ $\mathrm{CO}_{2}$ mol quanta ${ }^{-1}$ for the 40 species (Table 3). The tree samples from the stands at 1000, 2000, and $3000 \mathrm{~m}$ were not significantly different with respect to their $\alpha$ means.

Leaf dark respiration $\left(R_{\mathrm{D}}\right)$ at ambient temperature varied between 0.25 and $1.52 \mu \mathrm{mol} \mathrm{CO} \mathrm{Cm}^{-2} \mathrm{~s}^{-1}$ with most species means ranging between 0.4 and $0.9 \mu \mathrm{mol} \mathrm{m}^{-2} \mathrm{~s}^{-1}$ (Table 3). The stand means of $R_{\mathrm{D}}$ did not differ significantly at 1000, 2000, and $3000 \mathrm{~m}$ a.s.l.

\section{Discussion}

Among-Species Variation in $A_{\text {sat }}$ in Species-Rich Tropical Forests

This study focuses on the photosynthetic capacity of mature trees with a size of at least $4 \mathrm{~m}$

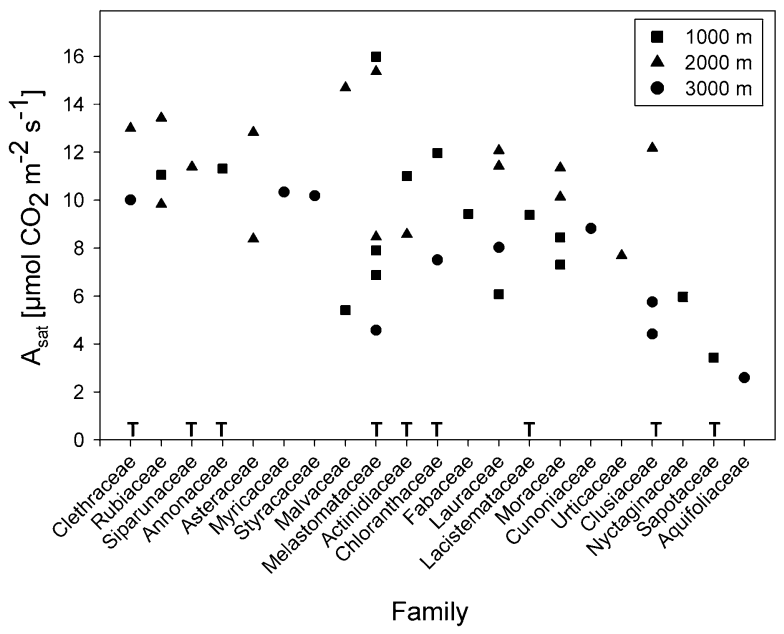

Figure 2. Net photosynthesis rate of sun leaves at ambient temperature and $\left[\mathrm{CO}_{2}\right]\left(A_{\text {sat }}\right)$ averaged over all species (morphotypes) of a family at a given elevation. The 21 families are arranged from left to right according to their mean $A_{\text {sat }}$ rate. $T$ indicate families with restriction to the tropics. 


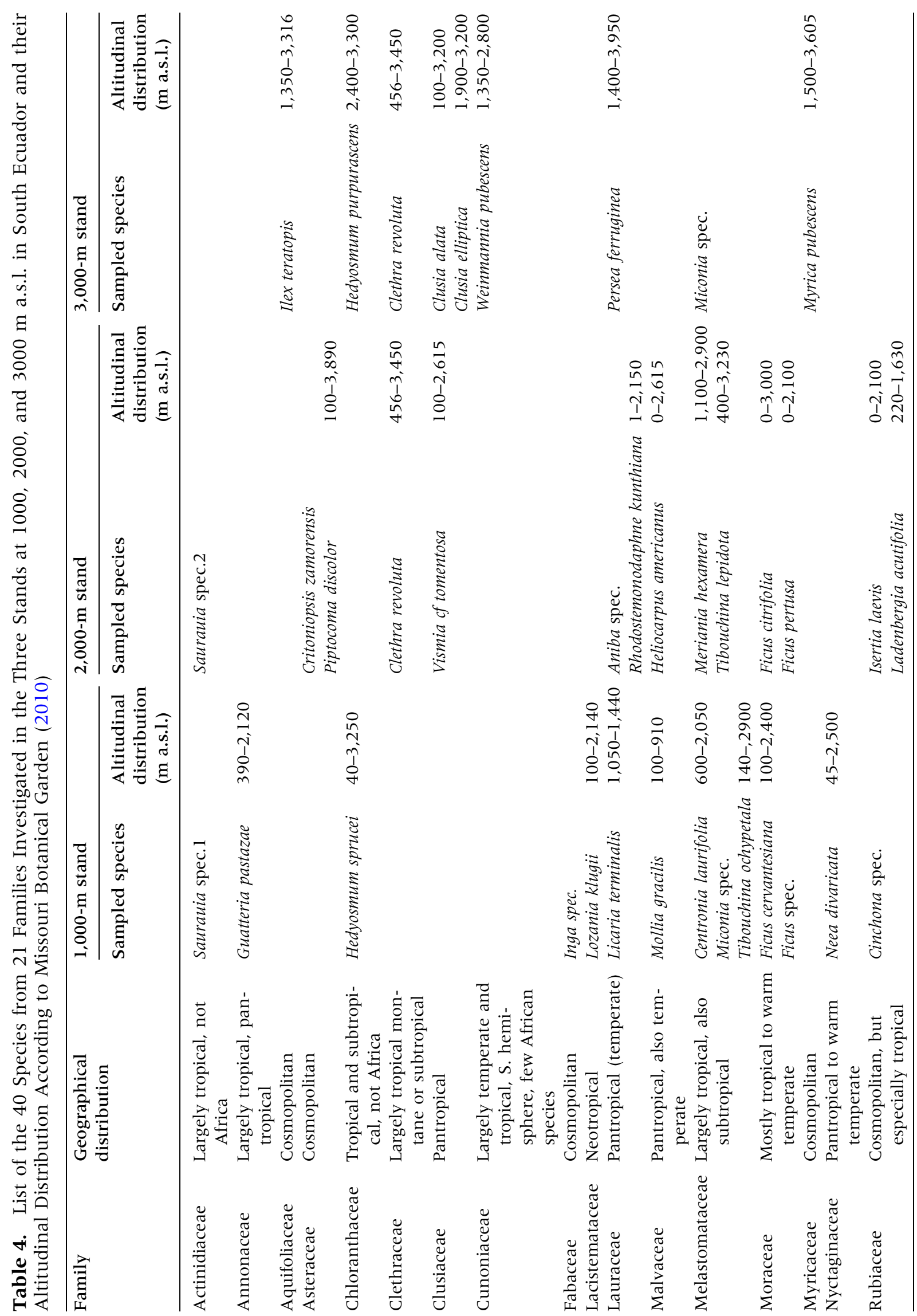


(uppermost stand), typically 8-20 m, to examine the maximum assimilation rate of sun-canopy leaves in their natural position in the canopy. We excluded seedling and sapling studies because leaf physiology may be subject to a considerable ontogenetic shift with tree aging (for example, Thomas and Winner 2002; Mediavilla and Escudero 2003). Measurements conducted in more than 155 species in about 18 stands in the Americas, South-east Asia, and Africa met the criteria defined in this study (see Table 1 in Online supplementary material).

In terms of species numbers, our study is the most comprehensive investigation conducted so far on the leaf-level photosynthesis of tropical trees; nevertheless, 155 species examined from a pool of approximately 37,000 taxa is still a tiny number. Similarly, our in-depth study on the 40 species of the Ecuadorian TMFs represents only about $5 \%$ of the 800 or so tree species in this study area (J. Homeier, unpublished data). Thus, the two species samples investigated may well not be representative of the local or the pantropical tree flora. The among-species variation in $A_{\text {sat }}$ in the three Ecuadorian stands was indeed considerable (coefficients of variation of 20 $38 \%$ ). Further bias may have been added to our data sets by the fact that we were not able to conduct a random selection of species or to choose them according to dominance in the three stands. Rather, species selection in Ecuador was confined to tree individuals growing on steep slopes because this allowed us to access part of their sun canopies with gas exchange equipment. This procedure guaranteed that the measured leaves were exposed to full sunlight at least part of the day and thus must have possessed partial or full sun leaf adaptation. The selection of tree species was based on extensive knowledge of the ecology and distribution of the taxa in the Loja region of South Ecuador (Homeier and others 2008); we chose only typical members of the closed natural forest and excluded shade-intolerant pioneer tree species. Furthermore, the phylogenetic diversity covered by our species sample was relatively large, including taxa from 21 families in the whole study, or 10-16 species from 9 to 12 families in each of the three stands (Table 4). However, we cannot rule out the possibility that a larger survey covering additional species and families would lead to different $A_{\text {sat }}$ stand averages than the figures reported here for the Ecuadorian and pantropical analysis.

\section{Constant or Decreasing Photosynthetic Capacity with Elevation?}

From our 40-species sample in Ecuador, a significant altitudinal trend in photosynthetic capacity at 
ambient $\left[\mathrm{CO}_{2}\right]$ and temperature did not manifest. However, we found a significantly higher $A_{\text {sat }}$ stand mean for the mid-elevation stand at 2,000 $\mathrm{m}$ than at lower and higher elevation, corresponding to higher foliar $\mathrm{P}$ and $\mathrm{N}$ concentrations at this elevation. Correspondingly, species with relatively high $A_{\text {sat }}$ values $\left(>10 \mu \mathrm{mol} \mathrm{CO} \mathrm{C}^{-2} \mathrm{~s}^{-1}\right)$ occurred mostly in this mid-elevation stand. To the best of our knowledge, our investigation is the first that examined altitudinal changes in $A_{\text {sat }}$ in species-rich tropical moist forests by measuring a large number of species in the adult stage and thus accounting for the characteristic species turnover along the slope. A few studies on altitudinal change in photosynthetic performance measured daily means of actual photosynthesis but not $A_{\text {sat }}$ (for example, Cavieres and others 2000) or derived estimates of photosynthetic activity from productivity data (for example, Kitayama and Aiba 2002). The only other transect study on altitudinal patterns in $A_{\text {sat }}$ in mature tropical trees focused on a single, polymorphic tree species (Metrosideros polymorpha, Myrtaceae) in the species-poor Hawaiian rainforests (Cordell and others 1999). Similar to our study, these authors found no change in $A_{\text {sat }}$ under ambient temperature and $\left[\mathrm{CO}_{2}\right]$ conditions between 100 and 2,500 m a.s.l. However, $A_{\text {sat }}$ varied at unusually low levels $\left(2.3-3.8 \mu \mathrm{mol} \mathrm{CO}_{2} \mathrm{~m}^{-2} \mathrm{~s}^{-}\right.$ $\left.{ }^{1}\right)$ across the Hawaiian transect. It may well be that this rather unproductive species reflects the specific conditions of isolated island forests, and that the results cannot simply be extrapolated to tropical forests on the continents. Moreover, altitudinal patterns in $A_{\text {sat }}$ derived from a single species with wide altitudinal distribution should differ from trends obtained from transect studies that cover a large number of species of different phylogenies, each adapted to the specific site conditions at the respective elevation level.

In the absence of other transect studies on gas exchange in tropical mountains, additional information on altitudinal change in $A_{\text {sat }}$ is provided by our pan-tropical literature survey (Table 1 in Online supplementary material). The data incorporated in this analysis were selected according to strict criteria with respect to tree size (mature or pre-mature trees only), successional status (no pioneer species), canopy position (sun-exposed branches only), measuring conditions (saturating light, typically $>1,200 \mu \mathrm{mol} \mathrm{m}{ }^{-2} \mathrm{~s}^{-1}$ PPFD; ambient temperature and $\left[\mathrm{CO}_{2}\right]$ ), and climate (tropical moist); this protocol excluded a number of studies on maximum photosynthesis of tropical trees that either worked with saplings, understorey or pioneer trees or apparently used non-saturating irradiances. According to this data compilation, sun leaf- $A_{\text {sat }}$ significantly decreases from tropical lowland to upper montane elevation which contradicts our first hypothesis. The linear regression equation indicates a decrease in $A_{\text {sat }}$ by about $1.3 \mu \mathrm{mol}$ $\mathrm{CO}_{2} \mathrm{~m}^{-2} \mathrm{~s}^{-1}$ per $\mathrm{km}$ altitude (Figure 3: left column) or by about $0.20 \mu \mathrm{mol} \mathrm{CO}_{2} \mathrm{~m}^{-2} \mathrm{~s}^{-1}$ per $\mathrm{K}$ air temperature reduction (Figure 3: center column). The trees from lowland forests reached average photosynthetic capacities of about $10-11 \mu \mathrm{mol}$ $\mathrm{CO}_{2} \mathrm{~m}^{-2} \mathrm{~s}^{-1}$, those of the upper montane forests of about $7 \mu \mathrm{mol} \mathrm{CO} \mathrm{CO}_{2} \mathrm{~m}^{-2} \mathrm{~s}^{-1}$. The decrease in areabased $A_{\text {sat }}$ coincides not only with the temperature decrease but also with a significant decrease in foliar P whereas no significant $N_{\mathrm{m}}$ decrease with elevation was detected in the pantropical survey. Not only area-based, but mass-based $A_{\text {sat }}$ decreased also from lowland to upper montane elevation $(P=0.004$; data of Table 1 in Online supplementary material); this indicates that the altitudinal increase in LMA, which occurred between lowland and montane elevation, was on the average not large enough to compensate the mass-based $A_{\text {sat }}$ reduction and thus to prevent a decrease in areabased $A_{\text {sat }}$.

Local edaphic and climatic conditions seem to modify this more general picture of altitudinal change in area- and mass-based $A_{\text {sat }}$ considerably. Although the Ecuadorian data generally fit quite well into the patterns extracted from the pantropical analysis, $A_{\text {sat }}$ deviates with relatively high rates at mid-slope position $(2,000 \mathrm{~m})$ from the overall trend which is explained by the relatively high soil $\mathrm{P}$ availability in this stand. With a mean foliar $\mathrm{P}$ concentration of $1.1 \mathrm{mg} \mathrm{g}^{-1}$, the 2,000-m stand fits well into the "moderately fertile" category of Vitousek and Sanford (1986) for lowland forests, whereas the 1,000- and 3,000-m stands with $0.5 \mathrm{mg} \mathrm{P} \mathrm{g}^{-1}$ must be classified as "infertile." The very high annual rainfall amount in the 3,000-m stand, in combination with high cloudiness, poor soil aeration, and low decomposition rates, is another site-specific factor in the Ecuador transect that may have influenced $A_{\text {sat }}$. Upper montane forests studied in Peru at a similar elevation received only half the rainfall amount (van de Weg and others 2009) and thus grew under less extreme conditions.

The lowered $A_{\text {sat }}$ of TMF trees was evident from our analysis, even though the among-species variation was large and local edaphic and climatic factors seem to modify the effect of elevation and temperature considerably. The relatively low $A_{\text {sat }}$ differentiates TMF trees functionally from tropical lowland trees. This difference matches with the 

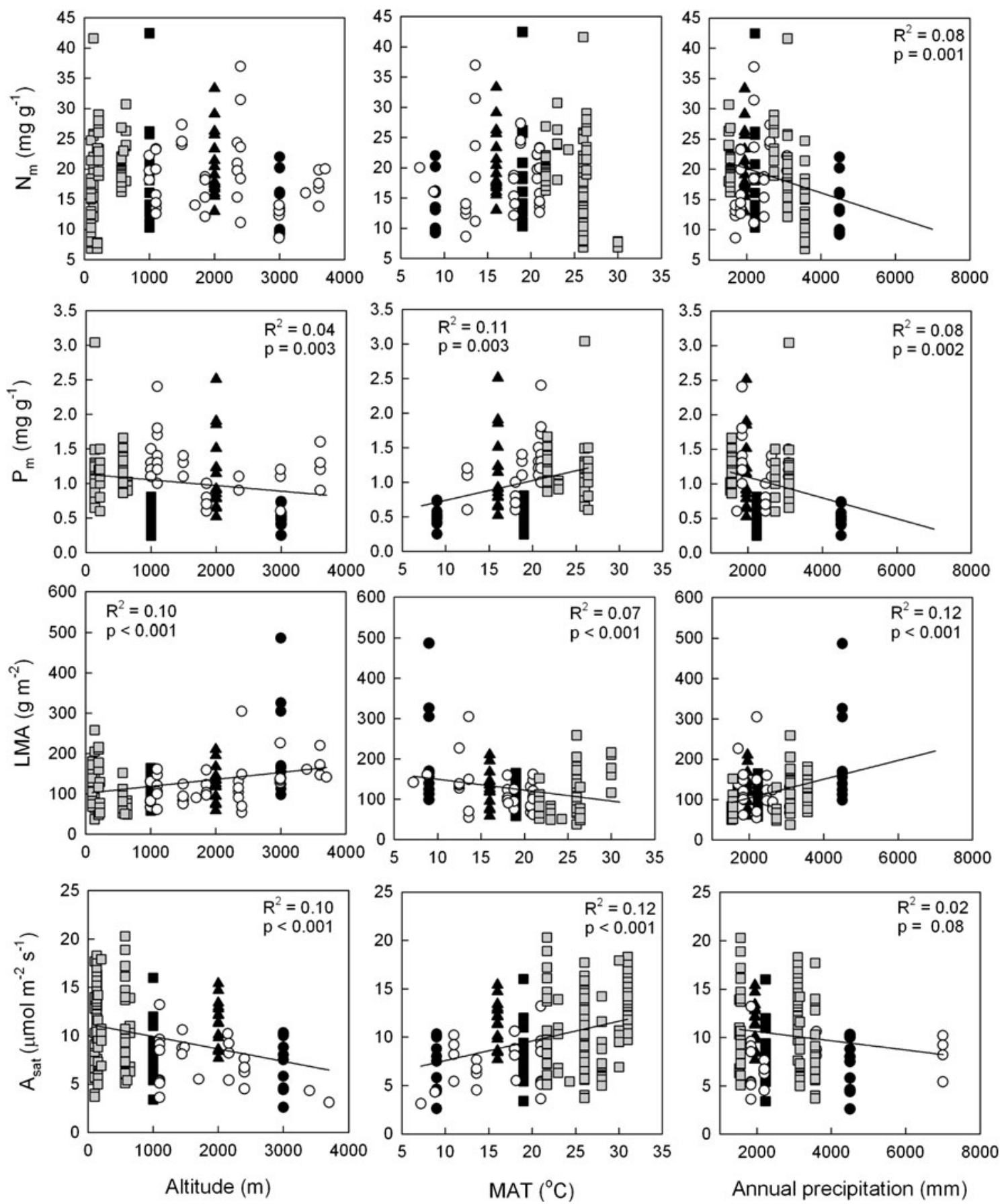

Figure 3. Dependence of light-saturated net photosynthesis at ambient temperature and $\left[\mathrm{CO}_{2}\right]\left(A_{\mathrm{sat}}\right)$, foliar nitrogen $\left(N_{\mathrm{m}}\right)$, and phosphorus $\left(P_{\mathrm{m}}\right)$ concentrations (mass based), and leaf mass per area (LMA) on elevation, temperature, and precipitation in a pan-tropical data set of c. 170 tree species and 18 forest stands. Only data referring to mature or premature tree individuals (no seedlings or saplings) of non-pioneer stands were included. For further explanations and references see Table 1 in online supplementary material. Filled gray symbols data from lowland forests; black filling data from this study in southern Ecuador (squares 1,000-m stand, triangles 2,000-m stand, and circles 3,000-m stand).

MAT and MAP characteristics of the investigated TMF stands which place this tree group closer to the trees of temperate evergreen rainforests or temperate deciduous forests than to tropical lowland forests (Figure 4); certain TMF stands with extremely high precipitation are even falling outside any biome range as defined by Wright and others (2004). A more detailed analysis of leaf trait 


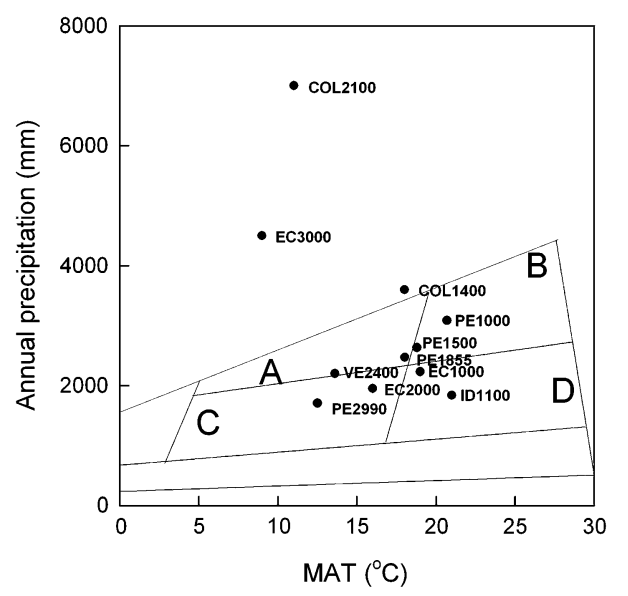

Figure 4. Grouping of the tropical montane forests considered in this study in the major biomes of the world (after Wright and others 2004) using annual precipitation and mean annual temperature as criteria. Accordingly, these tropical montane forests have affiliations to temperate rain forests $(A)$, tropical rainforests $(B)$, temperate forests $(C)$, or tropical seasonal forests $(D)$. Only sites located between 1,000 and 3,600 $\mathrm{m}$ a.s.l. are included. Locations: Ecuador (EC1000, EC2000, and EC3000, this study), Peru (PE1000, PE1500, PE1855, and PE2990, van de Weg and others 2012), Colombia (CO1445, CO2145, Letts and Mulligan, 2005), Venezuela (VE2400, Rada and others), and Indonesia (ID1100, Hölscher and others 2006).

relationships in the TMF tree sample shows that this group is partly deviating from the pattern of $A_{\text {sat }}-$ foliar N-LMA inter-relationships as they appear from a global perspective in the leaf economics spectrum of Wright and others (2004) (Figure 5). One striking difference is the large scatter of the data in the plot of mass-based $A_{\text {sat }}$ against SLA and $N_{\mathrm{m}}$ in TMF trees. The surprisingly low mass-based
$A_{\text {sat }}$ rates in several leaves of the TMF sample with high SLA might point at plant-internal $\mathrm{N}$ allocation patterns that are directed to an optimization of light capture at the expense of maximum carboxylation rate (Evans 1989), in a similar manner as has been found in tropical understorey plants (Santiago and Wright 2007). In contrast to tropical lowland trees, many montane forest trees are exposed to continuously high cloudiness and low-light conditions which could explain this apparent functional difference from lowland trees. High variation in SLA at a relatively narrow range of mass-based $A_{\text {sat }}$ rates may offer a greater potential for optimizing $\mathrm{CO}_{2}$ assimilation in this cool, often light-limited environment (Givnish 1988; Sims and others 1994; Santiago and Wright 2007).

Our literature survey further suggests that the range of $A_{\text {sat }}$ species means occurring in lowland forests $\left(3.7-20.3 \mu \mathrm{mol} \mathrm{CO} \mathrm{CO}^{-2} \mathrm{~s}^{-1}\right)$ is larger than that in montane and upper montane stands (2.1$13.2 \mu \mathrm{mol} \mathrm{m} \mathrm{m}^{-2} \mathrm{~s}^{-1}$ ). The apparent decrease in $A_{\text {sat }}$ variation with increasing elevation is partly caused by the uneven distribution of data over the elevation range with fewer trees being studied at altitudes above $1,500 \mathrm{~m}$ than at lower elevation. However, the upslope decrease in the number of investigated species mirrors the general decrease in tree species richness from tropical lowland to montane elevation (Gentry 1988, 1995; Aiba and Kitayama 1999; Slik and others 2009) and thus seems to be justified.

A functional explanation of the upslope reduction in $A_{\text {sat }}$ variation is provided by stand differences in canopy structure. We expect that taller multilayered lowland forests should generate a spatially more heterogeneous light climate than the structurally simpler high-elevation forests. This
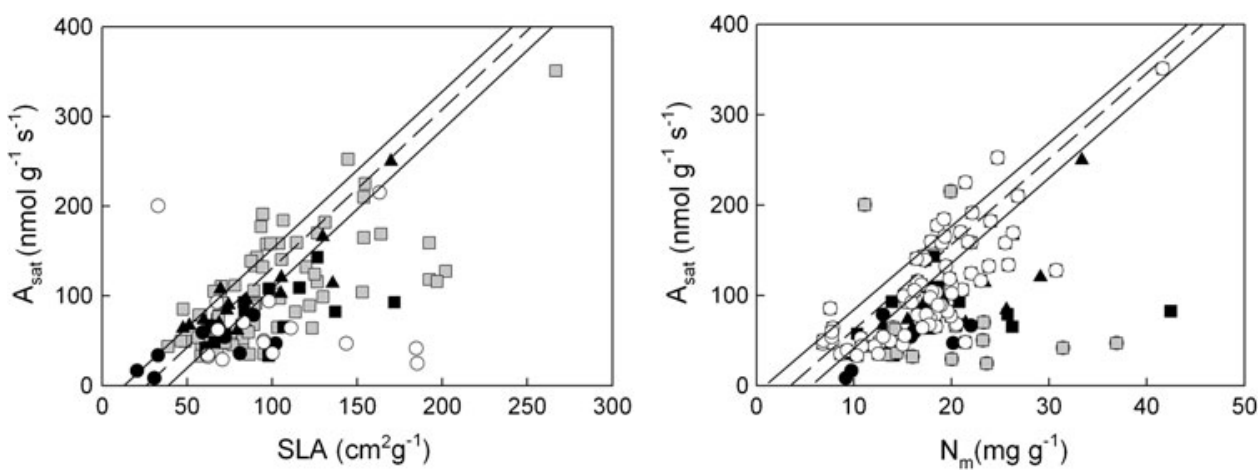

Figure 5. Relationships between photosynthetic rate per mass $\left(A_{\text {sat }}\right)$ and (left) specific leaf area (SLA) or (right) leaf nitrogen per mass $\left(N_{\mathrm{m}}\right)$ for the tree species in the survey. Filled symbols are for species from montane locations with black filling indicating the Ecuadorian species of this study (squares 1,000-m stand, triangles 2,000-m stand, circles 3,000-m stand) and gray filling species from other montane sites, open symbols stand for all other species in the survey. Dashed lines represent model II regressions with 95\% confidence intervals for the global data set of Santiago and Wright (2007) (GLOPNET). 
would allow at lower altitude the coexistence of more tree species with different strategies of light use and carbon assimilation. We assume that the large $A_{\text {sat }}$ variation in the lowland data of our literature survey (maxima up to $20 \mu \mathrm{mol} \mathrm{CO}_{2} \mathrm{~m}^{-2}$ $\mathrm{s}^{-1}$ ) is mirroring the co-existence of species from the full spectrum of tree functional types that are present in old-growth lowland forests, notably shade-tolerant late-successional and lightdemanding gap species (Turner 2001). High-elevation forests of low stature, in contrast, are typically dense with only a single main canopy layer in which the among-species variation in photosynthetic capacity $\left(A_{\text {sat }}\right.$ typically $\left.<8 \mu \mathrm{mol} \mathrm{CO}_{2} \mathrm{~m}^{-2} \mathrm{~s}^{-1}\right)$ is indeed reduced. In the neotropical high-elevation tree genus Polylepis, which forms the highest forests of the world, the largest observed $A_{\text {sat }}$ values do not exceed $9 \mu \mathrm{mol} \mathrm{CO} \mathrm{CO}_{2} \mathrm{~m}^{-2} \mathrm{~s}^{-1}$ in Argentina $(2,100 \mathrm{~m}), \quad 7 \mu \mathrm{mol} \mathrm{CO} \mathrm{CO}^{-2} \mathrm{~s}^{-1}$ in Venezuela $(4,200 \mathrm{~m})$, and $3 \mu \mathrm{mol} \mathrm{CO} \mathrm{m}^{-2} \mathrm{~s}^{-1}$ in Bolivia (4,300 m, Rada and others 1996; Azocar and others 2007). Accordingly, it is not very likely that a future more extensive set of photosynthesis data from tropical high-elevation tree species would result in higher mean $A_{\text {sat }}$ values than those reported in this study.

What are the underlying causes of the apparent $A_{\text {sat }}$ decrease with elevation? The direct or indirect air pressure effects on $A_{\text {sat }}$ are probably small, in particular at low temperatures, as indicated by modeling studies of Terashima and others (1995) and Smith and Hughes (2009). A more likely explanation would be the effect of lowered temperature on the rate of RuBP carboxylation, that is, reduced light-saturated photosynthesis rates of montane and upper montane tree species under the lowered ambient temperatures of their growing sites. Low temperatures can reduce enzyme activity in the photosynthetic apparatus or may cause feedback inhibition of photosynthesis because of impaired sucrose metabolism and phloem loading. However, alpine and arctic plants have been found to compensate effectively for low temperatures by increasing Rubisco concentration and carboxylation capacity which is reflected by the generally relatively high foliar $\mathrm{N}$ concentrations (Körner and Larcher 1988; Körner 1989). A prerequisite of such a compensatory response is a sufficiently high $\mathrm{N}$ and P supply which existed in the Ecuador TMF at $2,000 \mathrm{~m}$, but $\mathrm{N}$ and $\mathrm{P}$ were in short supply at 3,000 $\mathrm{m}$ (Moser and others 2011). Suppression of photosynthetic capacity by shortage of $\mathrm{N}$ or $\mathrm{P}$ (or other elements) in montane and upper montane forests is a possible scenario because the rate of nutrient cycling generally decreases at higher elevations with a reduction in temperature (Benner and others 2010). We found markedly smaller average foliar $\mathrm{N}$ concentrations in the $3000-\mathrm{m}$ stand than in the other two forests (difference significant to the 2000-m stand). Growing deterioration of $\mathrm{N}$ and/or P supply with increasing elevation could limit the photosynthetic capacity of high-altitude trees by two mechanisms, by restricting the amount of $\mathrm{N}$ and $\mathrm{P}$ available for allocation to the photosynthetic machinery or by increasing mean leaf longevity and thus mean leaf age; longer living leaves are typically more sclerophyllous and physiologically less active (Reich and others 1991; Wright and others 2004). In fact, Moser and others (2007) found tree leaf longevity to increase from 16 to 25 months on average between 1,000- and 3,000-m elevation. Further studies are needed to identify both the biotic and the abiotic factors causing $A_{\text {sat }}$ to decrease with elevation in tropical mountains.

As predicted, the stand means of leaf dark respiration measured at ambient temperature remained constant along the elevation transect indicating effective adaptation of mitochondrial respiration of the montane and upper montane trees to the 10-K temperature gradient in Ecuador. Similar homeostatic responses of leaf dark respiration were reported from gradient studies with Eucalyptus pauciflora and herbaceous plants growing at different elevations (Larigauderie and Körner 1995; Atkin and others 2000a, b, 2006).

\section{Conclusions}

Altitudinal gradient studies may provide valuable insights into the temperature dependence of tree growth and the forest carbon balance. Canopy $\mathrm{C}$ gain is a key element of the $\mathrm{C}$ balance, but how this flux is altered with altitude in response to decreasing temperature, atmospheric $\left[\mathrm{CO}_{2}\right]$, and other factors, that change with elevation, is not well understood. The detection of more general patterns of altitudinal change in $A_{\text {sat }}$ in tropical forests has long been hindered by the often high species diversity and difficult canopy access. Our combined approach of gas exchange screening in a large sample of pre-montane to upper montane neotropical tree species and a pan-tropical literature survey of carefully selected $A_{\text {sat }}$ data from low to high elevation revealed (1) a linear decrease from sea level to the alpine tree in the stand-level average of (mass- and area-related) $A_{\text {sat }}$ measured at ambient conditions, and (2) a decreasing range of among-species $A_{\text {sat }}$ variation with altitude. However, the data also suggest that (3) mountain 
transects with different geology and thus soil $\mathrm{N}$ and $\mathrm{P}$ availabilities might differ in their altitudinal $A_{\text {sat }}$ patterns. Our findings have implications for the search for the causes of alpine tree lines in tropical mountains. It appears that stands close to the tropical alpine tree line are built by tree species with reduced $A_{\text {sat }}$ rates, but, in addition, a reduced stand leaf area also contributes to a decrease in canopy $\mathrm{C}$ gain with increasing altitude in tropical mountains (Moser and others 2007). We interpret this result as a strong hint to carbon source limitation in tropical high-elevation forests, not supporting the hypothesis of $\mathrm{C}$ sink limitation as the principal cause of alpine tree lines (Körner 2003). Our results are in accordance with several recent studies that questioned the idea of carbon saturation in trees at high elevations (for example, Millard and others 2007; Susiluoto and others 2007; Li and others 2008).

\section{ACKNOWLEDGMENTS}

The authors are indebted to the German Academic Exchange Service (DAAD) for funding part of the field work and the DFG (FOR 816, subproject A2.2) for financial support. Logistic support by the Foundation Nature and Culture International (NCI, San Diego-Loja) is gratefully acknowledged. We thank the Ministerio del Ambiente de Ecuador for the research permit and Paul Gonzales and Linda Rohnstock for field assistance.

\section{OPEN ACCESS}

This article is distributed under the terms of the Creative Commons Attribution License which permits any use, distribution, and reproduction in any medium, provided the original author(s) and the source are credited.

\section{REFERENCES}

Aiba S, Kitayama K. 1999. Structure, composition and species diversity in an altitude-substrate matrix of rain forest tree communities on Mount Kinabalu, Borneo. Plant Ecol 140:139-57.

APG [=Angiosperm Phylogeny Group] III. 2009. An update of the angiosperm phylogeny group classification for the orders and families of flowering plants: APG III. Bot J Linn Soc 161:105-21.

Atkin OK, Evans JR, Ball MC, Lambers H, Pons TL. 2000a. Leaf respiration of snow gum in the light and dark. Interactions between temperature and irradiance. Plant Phys 122:915-24.

Atkin OK, Holly C, Ball MC. 2000b. Acclimation of snow gum (Eucalyptus pauciflora) leaf respiration to seasonal and diurnal variations in temperature: the importance of changes in the capacity and temperature sensitivity of respiration. Plant Cell Environ 23:15-26.
Atkin OK, Scheurwater I, Pons TL. 2006. High thermal acclimation potential of both photosynthesis and respiration in two lowland Plantago species in contrast to an alpine congeneric. Glob Change Biol 12:500-15.

Azocar A, Rada F, Garcia-Nunez C. 2007. Functional characteristics of the arborescent genus Polylepis along a latitudinal gradient in the high Andes. Interciencia 32:663-8.

Bendix J, Homeier J, Cueva Ortiz E, Emck P, Breckle S-W, Richter M, Beck E. 2006. Seasonality of weather and tree phenology in a tropical evergreen mountain rain forest. Int $\mathrm{J}$ Biometeorol 50:370-84.

Benecke U, Schulze E-D, Matyssek R, Havranek WM. 1981. Environmental control of $\mathrm{CO}_{2}$-assimilation and leaf conductance in Larix decidua Mill. Oecologia 50:54-61.

Benner J, Vitousek PM, Ostertag R. 2010. Nutrient cycling and nutrient limitation in tropical montane cloud forests. In: Bruijnzeel LA, Scatena FN, Hamilton LS, Eds. tropical montane cloud forests. Cambridge: Cambridge University Press. p 90-100.

Bresson CC, Kowalski AS, Kremer A, Delzon S. 2009. Evidence of altitudinal increase in photosynthetic capacity: gas exchange measurements at ambient and constant $\mathrm{CO}_{2}$ partial presssure. Ann For Sci 66:505.

Bruijnzeel LA, Scatena FN, Hamilton LS. 2010. Tropical montane cloud forests. Cambridge: Cambridge University Press.

Carswell FE, Meir P, Wandelli E, Bonates LCM, Kruijt B, Barbosa EM, Nobre AD, Grace J, Jarvis PG. 2000. Photosynthetic capacity in a central Amazonian rain forest. Tree Physiol 20:179-86.

Cavieres LA, Rada F, Azocar A, Garcia-Nunez C, Cabrera HM. 2000. Gas exchange and low temperature resistance in two tropical high mountain tree species from the Venezuelan Andes. Acta Oecol 21:203-11.

Cordell S, Goldstein G, Mueller-Dombois D, Webb D, Vitousek PM. 1998. Physiological and morphological variation in Metrosideros polymorpha, a dominant Hawaiian tree species, along an altitudinal gradient: the role of phenotypic plasticity. Oecologia 113:188-96.

Cordell S, Goldstein G, Meinzer FC, Handley LL. 1999. Allocation of nitrogen and carbon in leaves of Metrosideros polymorpha regulates carboxylation capacity and $\delta^{13} \mathrm{C}$ along an altitudinal gradient. Funct Ecol 13:811-18.

Eschenbach C, Glauner R, Kleine M, Kappen L. 1998. Photosynthesis rates of selected tree species in a lowland dipterocarp rainforest of Sabah, Malaysia. Trees Struct Funct 12:356-65.

Evans JR. 1989. Photosynthesis and nitrogen relationships in leaves of C-3 plants. Oecologia 78:9-19.

Gentry AH. 1988. Tree species richness of upper Amazonian forests. Proc Natl Acad Sci USA 85:156-9.

Gentry AH. 1995. Patterns of diversity and floristic composition in neotropical montane forests. In: Churchill $\mathrm{H}$, Balslev $\mathrm{H}$, Forero E, Luteyn JL, Eds. Biodiversity and conservation of neotropical montane forests. New York: New York Botanical Garden. p 103-26.

Ghazoul J, Sheil D. 2010. Tropical rain forest ecology, diversity, and conservation. Oxford: Oxford University Press.

Girardin CAJ, Malhi Y, Aragão L, Mamani M, Huaraca Huasco W, Durand L, Feeley KJ, Rapp J, Silva-Espejo JE, Silman MR, Salinas N, Whittaker RJ. 2010. Net primary productivity and its allocation along a tropical forest elevational transect in the Peruvian Andes. Glob Change Biol 16:3176-92. 
Givnish TJ. 1988. Adaptation to sun and shade-a whole-plant perspective. Aust J Plant Physiol 15:63-92.

Grubb PJ. 1977. Control of forest growth and distribution on wet tropical mountains: with special reference to mineral nutrition. Ann Rev Ecol Syst 8:83-107.

Grubb PJ, Tanner EVJ. 1976. The montane forests and soils of Jamaica: a reassessment. J Arnold Arboretum 57:33-68.

Hamilton LS, Juvik JO, Scatena FN. 1995. Tropical montane cloud forests. New York: Springer.

Hikosaka K, Nagamatsu D, Ishii HS, Hirose T. 2002. Photosynthesis-nitrogen relationships in species at different altitudes on Mount Kinabalu, Malaysia. Ecol Res 17:305-13.

Hoch G, Popp M, Körner C. 2002. Altitudinal increase of mobile carbon pools in Pinus cembra suggests sink limitation of growth at the Swiss treeline. Oikos 98:361-74.

Hölscher D, Leuschner C, Bohmann K, Hagemeier M, Juhrbandt J, Tjitrosemito S. 2006. Leaf gas exchange of trees in oldgrowth and young secondary forest stands in Sulawesi, Indonesia. Trees 20:278-85.

Homeier J, Werner FA, Gradstein SR, Breckle S-W, Richter M. 2008. Potential vegetation and floristic composition of Andean forests in South Ecuador, with a focus on the RBSF. In: Beck E, Bendix J, Kottge I, Makeschin F, Mosandl R, Eds. Gradients in a tropical mountain ecosystem of ecuador. Berlin: Springer. p 87-100.

Kenzo T, Ichie T, Yoneda R, Kitahashi Y, Watanabe Y, Ninomiya I, Koike T. 2004. Interspecific variation of photosynthesis and leaf characteristics in canopy trees of five species of Dipterocarpaceae in a tropical rain forest. Tree Physiol 24:1187-92.

Kitayama K, Aiba S-I. 2002. Ecosystem structure and productivity of tropical rain forests along altitudinal gradients with contrasting soil phosphorus pools on Mount Kinabalu, Borneo. J Ecol 90:37-51.

Körner C. 1989. The nutritional status of plants from high altitudes. Oecologia 81:379-91.

Körner C. 2003. Alpine plant life: functional plant ecology of high mountain ecosystems. Berlin: Springer.

Körner C, Larcher W. 1988. Plant life in cold climates. Symp Soc Exp Biol 42:25-57.

Larigauderie A, Körner C. 1995. Acclimation of leaf dark respiration to temperature in alpine and lowland plant species. Ann Bot 76:245-52.

Letts MG, Mulligan M. 2005. The impact of light quality and leaf wetness on photosynthesis in north-west Andean tropical montane cloud forest. J Trop Ecol 21:549-57.

Leuschner C, Zach A, Moser G, Homeier J, Graefe S, Hertel D, Wittich B, Soethe N, Iost S, Röderstein M, Horna V, Wolf K. in press. The carbon balance of tropical mountain forests along an altitudinal transect, Southern Ecuador. In: Bendix J, Beck E, Makeschin F, Mosandl R, Scheu S, Eds. Ecological studies. Berlin: Springer.

Li MH, Xiao WF, Wang SG, Cheng GW, Cherubini P, Cai XH, Liu XL, Wang XD, Zhu WZ. 2008. Mobile carbohydrates in Himalayan treeline trees I. Evidence for carbon gain limitation but not for growth limitation. Tree Physiol 28:1287-96.

Lieberman D, Lieberman M, Peralta R, Hartshorn GS. 1996. Tropical forest structure and composition on a large-scale altitudinal gradient in Costa Rica. J Ecol 84:137-52.

Mediavilla S, Escudero A. 2003. Mature trees versus seedlings: differences in leaf traits and gas exchange patterns in three cooccurring Mediterranean oaks. Ann For Sci 60:455-60.
Meir P, Levy PE, Grace J, Jarvis PG. 2007. Photosynthetic parameters from two contrasting woody vegetation types in West Africa. Plant Ecol 192:277-87.

Millard P, Sommerkorn M, Grelet G-A. 2007. Environmental change and carbon limitation in trees: a biochemical, ecophysiological and ecosystem appraisal. New Phytol 175:11-28.

Missouri Botanical Garden. 2010. Tropicos.org. http://www. tropicos.org. Accessed 10 Nov 2010.

Moser G, Hertel D, Leuschner C. 2007. Altitudinal change in LAI and stand leaf biomass in tropical montane forests: a transect study in Ecuador and a pan-tropical meta-analysis. Ecosystems 10:924-35.

Moser G, Roederstein M, Soethe N, Hertel D, Leuschner C. 2008. Altitudinal changes in stand structure and biomass allocation of tropical mountain forests in relation to microclimate and soil chemistry. In: Beck E, Bendix J, Kottke I, Makeschin F, Mosandl R, Eds. Gradients in a tropical mountain ecosystem of Ecuador, ecological studies 198. Berlin: Springer. p 229-42.

Moser G, Leuschner C, Röderstein M, Graefe S, Soethe N, Hertel D. 2010. Biomass and productivity of fine and coarse roots in five tropical mountain forest stands along an altitudinal transect in southern Ecuador. Plant Ecol Divers 3:151-64.

Moser G, Leuschner C, Hertel D, Graefe S, Soethe N, Iost S. 2011. Elevation effects on the carbon budget of tropical mountain forests (S Ecuador): the role of the belowground compartment. Glob Change Biol 17:2211-26.

Odegaard F. 2000. How many species of arthropods? Erwin's estimate revised. Biol J Linnean Soc 71:583-97.

Pollmann W, Hildebrand R. 2005. Structure and the composition of species in timberline ecotones of the Southern Andes. In: Broll G, Keplin B, Eds. Mountain ecosystems-studies in treeline ecology. Berlin: Springer. p 117-51.

Premoli AC, Brewer CA. 2007. Environmental v. genetically driven variation in ecophysiological traits of Nothofagus pumilio from contrasting elevations. Aust J Bot 55:585-91.

Rada F, Azócar A, Briceño B, González J, García-Núñez C. 1996. Carbon and water balance in Polylepis sericea, a tropical treeline species. Trees Struct Funct 10:218-22.

Rada F, García-Núnez C, Ataroff M. 2009. Leaf gas exchange in canopy species of a Venezuelan cloud forest. Biotropica 41:659-64.

Raich JW, Russell AE, Vitousek PM. 1997. Primary productivity and ecosystem development along an elevational gradient on Mauna Loa, Hawai'i. Ecology 78:707-21.

Reich PB, Uhl C, Walters MB, Ellsworth DS. 1991. Leaf life-span as a determinant of leaf structure and function among 23 Amazonian tree species. Oecologia 86:16-24.

Reich PB, Ellsworth DS, Walters MB, Vose JM, Gresham C, Volin JC, Bowman WD. 1999. Generality of leaf trait relationships: a test across six biomes. Ecology 80:1955-69.

Santiago LS, Wright SJ. 2007. Leaf functional traits of tropical forest plants in relation to growth form. Funct Ecol 21:19-27.

Santiago LS, Goldstein G, Meinzer FC, Fisher JB, Machado K, Woodruff D, Jones T. 2004. Leaf photosynthetic traits scale with hydraulic conductivity and wood density in Panamanian forest canopy trees. Oecologia 140:543-50.

Shi P, Körner C, Hoch G. 2008. A test of the growth-limitation theory for alpine tree line formation in evergreen and deciduous taxa of the eastern Himalayas. Funct Ecol 22:213-20.

Sims DA, Gebauer RLE, Pearcy RW. 1994. Scaling sun and shade photosynthetic acclimation of Alocasia macrorrhiza to wholeplant performance. 2. Simulation of carbon balance and 
growth at different photon flux densities. Plant Cell Environ 17:889-900.

Slayter R, Morrow P. 1977. Altitudinal variation in the photosynthetic characteristics of Snow Gum, Eucalyptus pauciflora Sieb. ex Spreng. I. Seasonal changes under field conditions in the snowy mountains area of south-eastern Australia. Aust J Bot 25:1-20.

Slik JWF, Raes N, Aiba S-I, Brearley FQ, Cannon CH, Meijaard E, Nagamasu H, Nilus R, Paoli G, Poulsen AD, Sheil D, Suzuki E, van Valkenburg JLCH, Webb CO, Wilkie P, Wulffraat S. 2009. Environmental correlates for tropical tree diversity and distribution patterns in Borneo. Divers Distrib 15:523-32.

Smith WK, Hughes NM. 2009. Progress in coupling plant form and photosynthetic function. Castanea 74:1-26.

Smith WK, Johnson D. 2009. Biophysical effects of altitude on plant gas exchange. In: De la Cabrerra E, Smith WK, Eds. Biophysical plant ecology: perspectives and trends. Los Angeles: University of California Press. p 257-80.

Soethe N, Lehmann J, Engels C. 2008. Nutrient availability at different altitudes in a tropical montane forest in Ecuador. $\mathrm{J}$ Trop Ecol 24:397-406.

Stevens, PF. 2010. Angiosperm Phylogeny Website. Version 9, June 2008. http://www.mobot.org/MOBOT/research/APweb/. Accessed 10 Nov 2010.

Susiluoto S, Perämäki M, Nikinmaa E, Berninger F. 2007. Effects of sink removal on transpiration at the treeline: implications for the growth limitation hypothesis. Environ Exp Bot 60:334-9.

Tanner EVJ, Vitousek PM, Cuevas E. 1998. Experimental investigation of nutrient limitation of forest growth on wet tropical mountains. Ecology 79:10-22.

Terashima I, Masuzawa T, Ohba H, Yokoi Y. 1995. Is photosynthesis suppressed at higher elevations due to low $\mathrm{CO}_{2}$ pressure? Ecology 76:2663-8.

Thomas SC, Winner WE. 2002. Photosynthetic differences between saplings and adult trees: an integration of field results by meta-analysis. Tree Physiol 22:117-27.

Turner IM. 2001. The ecology of trees in the tropical rain forest. Cambridge: Cambridge University Press. van de Weg MJ, Meir P, Grace J, Ramos GD. 2009. Altitudinal variation in leaf mass per unit area, leaf tissue density and foliar nitrogen and phosphorus content along an AmazonAndes gradient in Peru. Plant Ecol Divers 2:243-54.

van de Weg MJ, Meir P, Grace J, Atkin OK. 2012. Photosynthetic parameters, dark respiration and leaf traits in the canopy of a Peruvian tropical montane cloud forest. Oecologia 168:23-34.

Vitousek PM, Sanford JrRL. 1986. Nutrient cycling in moist tropical forest. Ann Rev Ecol Syst 17:137-67.

Wang HQ, Hall CAS, Scatena FN, Fetcher N, Wu W. 2003. Modelling the spatial and temporal variability in climate and primary productivity across the Luquillo Mountains, Puerto Rico. For Ecol Manage 179:69-94.

Weaver PL, Murphy PG. 1990. Forest structure and productivity in Puerto-Rico Luquillo Mountains. Biotropica 22:69-82.

Whitmore TC. 1998. An introduction to tropical rain forests. 2nd edn. Oxford: Oxford University Press.

Wieser G, Tausz M. 2007. Current concepts for treelife limitation at the upper timberline. In: Wieser G, Tausz M, Eds. Trees at their upper limit. Dordrecht: Springer. p 1-18.

Wieser G, Oberhuber W, Walder L, Spieler D, Gruber A. 2010. Photosynthetic temperature adaptation of Pinus cembra within the timberline ecotone of the Central Austrian Alps. Ann For Sci 67:201. doi:10.1051/forest/2009094.

Wright IJ, Reich PB, Westoby M, Ackerly DD, Baruch Z, Bongers F, Cavender-Bares J, Chapin T, Cornelissen JHC, Diemer M, Flexas J, Garnier E, Groom PK, Gulias J, Hikosaka K, Lamont BB, Lee T, Lee W, Lusk C, Midgley JJ, Navas ML, Niinemets U, Oleksyn J, Osada N, Poorter H, Poot P, Prior L, Pyankov VI, Roumet C, Thomas SC, Tjoelker MG, Veneklaas EJ, Villar R. 2004. The worldwide leaf economics spectrum. Nature 428:821-7.

Zhang J-L, Cao K-F. 2009. Stem hydraulics mediates leaf water status, carbon gain, nutrient use efficiencies and plant growth rates across dipterocarp species. Funct Ecol 23:658-67.

Zhang SB, Zhou ZK, Hu H, Xu K, Yan N, Li SY. 2005. Photosynthetic performances of Quercus pannosa vary with altitude in the Hengduan Mountains, southwest China. For Ecol Manage 212:291-301. 